For citation: Ekonomika regiona [Economy of Region]. - 2016. - Vol. 12, Issue 3. - pp. 695-702 doi 10.17059/2016-3-7

UDC 339.923

A. T. Spitsyn ${ }^{\text {a) }}$, G. A. Kulubekova ${ }^{\text {b) }}$

a) Russian Academy of National Economy and Public Administration (Moscow, Russian Federation)

b) L.N. Gumiliov Eurasian National University (Astana, Kazakhstan; e-mail: kulubekova.galiya@gmail.com)

\title{
EURASIAN ECONOMIC UNION AND PROSPECTS OF DEVELOPMENT OF TRANSNATIONAL CORPORATIONS IN THE FRAME OF THE GLOBALIZATION ${ }^{1}$
}

The purpose of this article is to study the processes of regional integration and its particular features in the frame of the Eurasian Economic Union formation and their impact on the development of transnational corporations in the region. The authors used the scientific and methodological basis including an integrated approach and economic, institutional and organizational methods, theoretical and methodological studies of domestic and foreign scientists. In order to achieve the defined aim of this research, the authors used the retrospective method and method of comparative analysis, studied the statistical data, including the reports of the United Nations Conference on Trade and Development and the World Bank's ratings. The authors studied the historical background of the Eurasian Economic Union, analyzed the current economic situation in its Member States, and considered the experience of other regional alliances. According to the results of the research, the authors formulated the conclusions in the context of the most likely prospects for the development of transnational corporations in the frame of the integration of the Member States of the Eurasian Economic Union. In particular, the study of the experience of other regional associations presumes that the process of regional economic integration will have a positive impact on the dynamics of the attraction of foreign direct investment inflows in the region. In addition, regional integration will mitigate the problem of "limited" markets of the Member States of the Economic Union and, therefore, will help to increase the amount of investment resources in the manufacturing industry and services sector of the economy. The creation of the common energy markets in the framework of the new regional association would strengthen the resource-oriented domestic large-scale business and prepare the groundwork for the emergence of new transnational corporations, cooperating within the Eurasian Economic Union. The research results can be applied in theory as a basis for the further studies of regional economic integration in the frame of the Eurasian Economic Union. Besides this, the analytical results of the research are of practical importance because they can be used for the purpose of the further development of the Eurasian Economic Union and harmonization of legislation of the Member States.

Keywords: Eurasian Economic Union (EAEU), European Union (EU), the potential of Eurasian integration, regional economic integration, integration development, foreign direct investment, transnational corporations

\section{Introduction}

The global processes and transnational corporations are the most important phenomena of the modern world economy and its transformation and globalization. Transnational capital (TNC) and its transnational corporations constitute the economic core of the globalization, being the driving force of the internationalization of production, the mobility of knowledge and information $[1$, p. 4]. The impact of these economic units on the modern world in XXI century can hardly be overestimated. XX century gave such a high incentive to the development of transnational corporations that within that period of time their compa-

\footnotetext{
${ }^{1}$ (c) Spitsyn A. T., Kulubekova G. A. Text. 2016.
}

nies and enterprises have become the major players on the world economic scene [2, p. 10; 3, p. 46].

The total value of the international production controlled by transnational corporations and their companies in the last quarter of XX century exceeded that of the international trade. The worldwide spread of transnational corporations and TNC accelerated. However, there were countries which on the basis of their political and social choices left no room for the participation of transnational corporations in their economies ${ }^{2}$. Such countries were out of cross-border traffic flows of direct investment and pursued the policy of self-sufficiency for dozens of years. The

\footnotetext{
2 UN Group of Eminent Persons (1974). The Impact of Multinational Corporations on Development and on International Relations. U.N. Doc. E/500/Rev. 1, St/ESA/6.
} 
most significant example of such a country was the Soviet Union. After its dissolution, the newly formed independent states faced the urgent need for the accelerated economic development. For this reason, the Post-Soviet countries were interested in attracting domestic and foreign direct investment (FDI), which was a strategic characteristic of the economic growth. This interest had been fixed during formation of the Post-Soviet states' legislation and found its reflection in the legal acts on foreign investments ${ }^{1}$. This position was not accidental: by the 1990s, transnational corporations alongside with FDI, which plays a fundamental role in the creation of these corporations, had become a significant part of the global market. At that moment, their position was stronger than it had been for the whole preceding period of last quarter of the XX century $[4$, p. $11 ; 5]$.

Besides this, the involvement of TNC, large transnational corporations and companies in the economies of many countries ensured significantly the political and social stability, alongside with protection of these corporations' property rights in a host country. From 1992 till now the attraction of FDI have served the development of national economies of the Post-Soviet territory $^{2}$, and have ensured the creation of large-scale transnational companies in the region.

The Eurasian Economic Union (EAEU) created on 2015 , as a new organization of regional economic integration, actively affects the economic development of the countries of the region, in particular, the development of national transnational companies and their cooperation with foreign corporations. The article aims to examine the prospects of the development of transnational corporations in the frame of the integration of the EAEU Member States with regard to the current particular features of the region.

\section{Methods of research and results}

The methodological aspect reveals the integration as an essential condition of the modern stage

\footnotetext{
${ }^{1}$ Law of the Russian Federation no. 160-FZ "On Foreign Investments in the Russian Federation"; Law of the Republic of Kazakhstan no. 373-II "On investments"; Law of the Republic of Belarus no. 53-3 "On investments"

${ }^{2}$ Data on the FDI inflows in Post-Soviet States from 1992 till 2014 are retrieved from UNCTAD reports: 1) UNCTAD (1997). World Investment Report: Transnational Corporations, market structure and competition policy. New York and Geneva, 303-309. Retrieved from: http://unctad.org/en/docs/wir1997 en.pdf (date of access: January 05, 2016). 2) UNCTAD (2015). World Investment Report: Reforming international investment governance. New York and Geneva, 65. Retrieved from: http:// unctad.org/en/PublicationsLibrary/wir2015_en.pdf (date of access: January 05, 2016).
}

of deep cooperation between the countries in the process of interstate coordination of manufacturers' cooperation (domestic and foreign transnational corporations) and their technological relationship on the Post-Soviet territory.

The scientific basis of the article includes the general theory of systems, the complex approach, the usage of the statistical comparisons' method, the institutional and legal methods, the scientific works of domestic and foreign scientists.

The used methods allowed the authors to determine the prerequisites for the establishment of the Eurasian Economic Union, which are essential for a common understanding of the development prospects of this new association. The comparative method was used to identify the characteristics of the impact of regional economic integration on foreign direct investment (FDI) inflows and development of transnational corporations in the region by the example of existing regional groupings such as the European Union and MERCOSUR. As a result, the article revealed the prospects of transnational corporations' development, including local companies, for the purposes of national economies within the framework of cooperation of the Eurasian Economic Union Member States with regard to the particular features of the functioning of this new regional association.

Such design of methods helped the authors to examine the prospects for the development of transnational corporations in the frame of the Eurasian Economic Union with the regard to the specific features of this new regional association.

Regional integration: from the Commonwealth of the Independent States (CIS) to the Eurasian Economic Union with regard to the European Union's experience.

The Eurasian Economic Union is a relatively new international organization of regional integration. In that regard, firstly, it is necessary to analyze the historical aspects that preceded to the creation of this regional association. For twenty years after the dissolution of the USSR, the independent states have taken several attempts to construct a regional economic community, because they realized that it would bring benefits to all its Member States.

The idea of the Eurasian Union was put forward during the speech of Nursultan Nazarbayev at the M. V. Lomonosov Moscow State University in March $1994^{3}$. This initiative of a new type of a union formed on the basis of the active joint ef-

\footnotetext{
${ }^{3}$ Nazarbayev, N. A. (1994). Speech at the Lomonosov Moscow State University. Eurasian initiatives of N. A. Nazarbayev: history, conditions, prospects: Scientific stock collection [Rech Moskovskom gosudarstvennom universitete im. Lomonosova.
} 
forts of mainly Russia and Kazakhstan has gained a truly remarkable strategic sense which has and will have a worthy place in the geopolitical construction of the future. The L. N. Gumilyov Eurasian National University established by the President of Kazakhstan in Astana in 1996 was a significant event: one of the priority tasks of the university was a scientific research in the field of integration processes, which became an important step towards the development of the intellectual Eurasianism.

"I think that during the years of real support for the idea of the Eurasian integration initiated by the President Nursultan Nazarbayev, the countries of the "triad" have already sacrificed a part of their sovereignty by creating a supranational body with certain powers, namely Eurasian Economic Commission”, said President of Belarus Alexander Lukashenko.

Nursultan Nazarbayev formulated the fundamental principles of regional integration which are embodied in the "Project on the formation of the Eurasian Union of States". It is focused on the inter-state cooperation and the integration of the countries of Eurasia. In the early 1990s, this strategy was aimed at assisting the newly independent states to overcome the negative consequences of the dissolution of the Soviet Union, as well as to preserve the common economic, political, transport and civilizational links which had existed between the peoples of Eurasia for centuries. The key instruments of "Eurasian project of N. A. Nazarbayev" had to be the efficient integration structures, such as the Customs Union, the Eurasian Economic Community, and the Common Economic Space. This integrity of the idea and the reality alongside with the systematic approach to consistent and constant onward movement ensured the success of the Eurasian project and the establishment of the Eurasian Economic Union [6, p. 13].

XXI century marked a new phase in the regional integration process. In 2000, five countries (Russia, Kazakhstan, Belarus, Tajikistan, and Kyrgyzstan) made a decision to establish the Eurasian Economic Community (EEC), which was the determinative step to regional economic integration [7, p. 187]. The Eurasian Economic Community was based on the concept of close and effective economic cooperation. The idea was supported by the countries which were the most prepared for the close integration and interaction in terms of political, legal and economic con-

Evraziyskie initsiativy N. A. Nazarbaeva: istoriya, sostoyanie, perspektivy: Nauchno-fondovyy sbornik]. Astana. ditions. In contrast to the Commonwealth of the Independent States, which had a huge range of goals and objectives, the EEC was initially positioned as an economic association.

In October 2007, Russia, Belarus, and Kazakhstan proposed an idea of a common customs territory, which resulted in signing the Treaty on establishing the Common Customs Territory and the Customs Union. The Customs Union became an entirely new form of integration within the Post-Soviet territory which had the supranational bodies and the unified legislation with the Customs Code. On 6th of July 2011, the Customs Code came into force within the entire territory of the Customs Union. Five days later, the customs control at the borders between Russia, Kazakhstan and Belarus was abolished; it was moved to the outer contour of the boundaries of the Member States of the Customs Union. The first step to the regional economic integration was taken.

In December 2010, Russia, Kazakhstan, and Belarus signed the Declaration on Eurasian economic integration in order to create the Common Economic Space. It was the second significant step towards the regional economic integration. The final integration step was done with the Treaty on the Eurasian Economic Union which was signed on May 29, 2014 in Astana. It came into force on January 1, 2015. By now it has been signed by five countries: Russia, Kazakhstan, Belarus, Armenia, and Kyrgyzstan. This treaty is the main document of the Eurasian Economic Union. It covers a huge range of issues from the customs regulation (section VIII), foreign trade policy (section IX) and coordinated macroeconomic policy (section XIII) to the formation of common energy markets of electric power, gas, oil and petroleum products (section XX), and industrial cooperation (section XXIV), etc. ${ }^{1}$

After the Treaty on the Eurasian Economic Union came into force several dozens of the international treaties which had been concluded before the establishment of the EAEU between its Member States, ceased to have an effect ${ }^{2}$, others apply only to the extent to which they are not inconsistent with the Treaty ${ }^{3}$. All lawmaking of the EAEU is based on this Treaty. The special position allotted to this document emphasizes the high tasks put on the EAEU in general.

\footnotetext{
${ }^{1}$ Treaty on the Eurasian Economic Union. Retrieved from: https://docs.eaeunion.org. English version is available at http:// www.un.org/en/ga/sixth/70/docs/treaty_on_eeu.pdf (date of access: January 14, 2016).

${ }^{2}$ Annex 33 of the Treaty on the Eurasian Economic Union.

${ }^{3}$ Art. 99 of the Treaty on the Eurasian Economic Union.
} 
Table 1

FDI inflows in the Post-Soviet States in 1992-2014

\begin{tabular}{|l|c|c|c|c|c|c|c|c|c|c|}
\hline \multirow{2}{*}{ Country } & \multicolumn{4}{|c|}{$\begin{array}{c}\text { FDI Inflows in 1992-1995 } \\
\text { (millions of dollars) }\end{array}$} & \multicolumn{5}{c|}{ FDI Inflows in 2009-2014 (millions of dollars) } \\
\cline { 2 - 14 } & $\mathbf{1 9 9 2}$ & $\mathbf{1 9 9 3}$ & $\mathbf{1 9 9 4}$ & $\mathbf{1 9 9 5}$ & $\mathbf{2 0 0 9}$ & $\mathbf{2 0 1 0}$ & $\mathbf{2 0 1 1}$ & $\mathbf{2 0 1 2}$ & $\mathbf{2 0 1 3}$ & $\mathbf{2 0 1 4}$ \\
\hline Armenia &.. &.. & 8 & 12 & 760 & 529 & 515 & 489 & 370 & 383 \\
\hline Azerbaijan &.. &.. & 22 & 275 & 473 & 563 & 1465 & 2005 & 2632 & 4430 \\
\hline Belarus & 7 & 10 & 15 & 7 & 1877 & 1393 & 4002 & 1429 & 2230 & 1798 \\
\hline Estonia & 82 & 162 & 215 & 202 & 1839 & 1024 & 974 & 1569 & 553 & 983 \\
\hline Georgia &.. &.. & 8 & 6 & 659 & 814 & 1048 & 911 & 949 & 1279 \\
\hline Kazakhstan & 100 & 150 & 185 & 280 & 13243 & 11551 & 13973 & 13337 & 10221 & 9562 \\
\hline Kyrgyzstan &.. &.. & 10 & 30 & 189 & 438 & 694 & 293 & 626 & 211 \\
\hline Latvia & 29 & 45 & 214 & 180 & 94 & 379 & 1453 & 1109 & 903 & 474 \\
\hline Lithuania & 10 & 30 & 31 & 73 & -14 & 800 & 1448 & 700 & 469 & 217 \\
\hline Moldova & 17 & 14 & 12 & 64 & 208 & 208 & 288 & 195 & 236 & 207 \\
\hline Russian Federation & 700 & 700 & 637 & 2017 & 36583 & 43168 & 55084 & 50588 & 69219 & 20958 \\
\hline Tajikistan &.. &.. & 10 & 13 & 16 & -15 & 70 & 233 & 105 & 263 \\
\hline Turkmenistan &.. &.. & 100 & 100 & 4553 & 3632 & 3391 & 3130 & 3076 & 3164 \\
\hline Ukraine & 200 & 200 & 159 & 267 & 4816 & 6495 & 7207 & 8401 & 4499 & 410 \\
\hline Uzbekistan & 40 & 45 & 50 & 120 & 842 & 1636 & 1635 & 563 & 686 & 751 \\
\hline
\end{tabular}

* Data are retrieved from UNCTAD reports: 1) UNCTAD (1997). World Investment Report: Transnational Corporations, market structure and competition policy. New York and Geneva. pp. 303-309. Retrieved from: http://unctad.org/en/docs/wir1997_ en.pdf (date of access: January 05, 2016). 2) UNCTAD (2015). World Investment Report: Reforming international investment governance. New York and Geneva. p. 65. Retrieved from: http://unctad.org/en/PublicationsLibrary/wir2015_en.pdf (date of access: January 05, 2016).

It is important to notice that the Treaty on the EAEU reveals some significant similarities between the EAEU and another international organization of regional integration, namely the European Union. The very first article of the Treaty on the EAEU ensures the so-called "four freedoms" among its Member States: freedom of movement of goods, capital, services, and labor. The EU ensures "four freedoms" as well: free movement of goods, capital, services and freedom of establishment. Besides this, the EAEU supranational bodies (Supreme Eurasian Economic Council, Eurasian Intergovernmental Council, Eurasian Economic Commission) are similar to the supranational organs of the EU (the European Council, the Council of the European Union, the European Commission). The similarity of the fundamental principles of two international organizations allowed the authors of the present article to take into account the experience of the EU for the analysis of regional integration prospects of EAEU Member States.

Perspectives of the development of transnational corporations in the frame of the Eurasian Economic Union.

The strategic location, the population and the territorial size of the EAEU show that the organization has the potential to become an important player in the international economy. The experience of other regional alliances helps to make certain assumptions about the impact of the EAEU on the national economies of its Member States, on the functioning of foreign transnational corporations.

The EAEU consists of five countries two of which (Russia and Kazakhstan) are the most invested Post-Soviet states (see Table 1), and, therefore, is a significant recipient of FDI in general.

On the basis of the EU experience, it is possible to suggest that the membership in the EAEU would be beneficial for such countries as Belarus, Armenia and Kyrgyzstan in terms of increasing FDI inflows. As it is possible to assume from Table 1, the FDI inflows in Armenia and Kyrgyzstan are quite low today. In Belarus, the situation seems better. In comparison with the global indicators, the investment attractiveness of Belarus has to increase in accordance with the National program of attracting investments into the economy of the Republic of Belarus for the period till 2010" and for further years. For this, it is necessary to create conditions to improve the investment attractiveness on the country-level.

The regional economic integration usually strengthens the stability of the economies of the participating countries and stimulates the inflows of domestic and foreign investment. For example, the EU membership stimulated the investment-led growth for Ireland, Portugal and Spain $[8 ; 15]$. The EU membership also attracted new FDI 
Table 2

FDI inflows before and after EU membership

\begin{tabular}{|l|c|c|c|c|c|}
\hline \multirow{2}{*}{ Country } & \multicolumn{5}{|c|}{ FDI inflows (millions of US dollars) } \\
\cline { 2 - 6 } & $\mathbf{2 0 0 1}$ & $\mathbf{2 0 0 2}$ & $\mathbf{2 0 0 3}$ & $\mathbf{2 0 0 4}$ & $\mathbf{2 0 0 5}$ \\
\hline Cyprus & 652 & 297 & 891 & 1079 & 1166 \\
\hline Czech Republic & 5639 & 9319 & 2101 & 4974 & 10991 \\
\hline Estonia & 542 & 307 & 919 & 1049 & 2853 \\
\hline Hungary & 2440 & 854 & 2137 & 4654 & 6699 \\
\hline Latvia & 164 & 396 & 292 & 699 & 632 \\
\hline Lithuania & 446 & 732 & 179 & 773 & 1009 \\
\hline Malta & 294 & 375 & 958 & 309 & 562 \\
\hline Poland & 5713 & 4119 & 4589 & 12873 & 7724 \\
\hline
\end{tabular}

* Data are retrieved from UNCTAD reports: 1) UNCTAD (2003). World Investment Report: FDI Policies for Development: National and International Perspectives. New York and Geneva, 250-252. Retrieved from: http://unctad.org/en/Docs/wir2003light_ en.pdf (date of access: December 17, 2015). 2) UNCTAD (2006). World investment report: FDI from Developing and Transition Economies: Implications for Development. New York and Geneva, 299-302. Retrieved from: http://unctad.org/en/Docs/wir2006_ en.pdf (date of access: December 17, 2015).

inflows to the countries that joined the Union in 2004 (see Table 2).

Alongside with this, for the Member States of the EAEU, it is necessary to play a key role not only in the increase of the general amount of FDI inflows, but also in the increase of the effectiveness of investment in the sphere of manufacturing industry and service sector. In the modern conditions, the Member States of EAEU have mostly natural resources oriented economies. For example, FDI in Armenia is targeted mainly in gold, silver, oil and gas [9, p. 111]. In Kyrgyzstan, the most investment-attractive field is a gold mining $[10, p$. 122].

Kazakhstan, despite the large inflows of FDI, slowly moves away from the natural resources orientation [11, p. 100]. Transnational corporations, which interests are represented in the country, have invested mainly in oil and gas fields (e.g., British Petroleum, Chevron Texaco, Exxon Mobil, Eni group, etc.). Thus, in the first half of 2014, the highest gross inflow of FDI in Kazakhstan was in the mining and quarrying sector (\$7473 million), $\$ 5730$ million of which were invested in the mining of crude oil and gas. In comparison, the gross inflow of FDI in the production of electrical equipment amounted to only $\$ 3.3$ million, in the production of vehicles and equipment amounted to $\$ 1.6$ million ${ }^{1}$.

Therefore, the attraction of the FDI inflows in the manufacturing industry and service sectors is a common problem for Kazakhstan, Belarus, Armenia, and Kyrgyzstan. One of the main ob-

\footnotetext{
${ }^{1}$ National Bank of the Republic of Kazakhstan. (2014). Balance of payments and external debt of the Republic of Kazakhstan for the first half of 2014. Retrieved from: http://www.nationalbank. kz/cont/publish183457_26910.pdf (date of access: December 17, 2015).
}

stacles in attracting FDI into these fields of the economy is the small size of the domestic market, which has to cover Kazakhstan (17.289 million people), Belarus (9.470 million people), Armenia (3.006 million people), Kyrgyzstan (5.834 million people $)^{2}$.

The formation of the single economic space and, therefore, the enlargement of the market to five countries, including Russia with its 143.819 million people population ${ }^{3}$ may improve the investment attractiveness of these four countries in the manufacturing industry and service sector of their economies.

Regarding this question, it is important to point out that Kazakhstan, Belarus, and Armenia are ranked higher for ease of doing business in comparison to Russia ${ }^{4}$. This fact might increase the investment attractiveness of these countries. Transnational corporations are interested in covering a larger market by less facility. Due to customs obstacles, it is better to invest than to try to export products. Therefore, the liberalization of the trade alongside with a friendly environment for business might help Kazakhstan, Armenia, and Belarus to receive the inflows of additional FDI into fields that were previously important only within the domestic market.

The example of changes within the manufacturing sector of Argentina (automobile in-

\footnotetext{
2 World Bank. (2010-2014). Population statistics. Retrieved from: http://data.worldbank.org/indicator/SP.POP.TOTL. (date of access: March 10, 2016).

${ }^{3}$ World Bank. (2010-2014). Population statistics. Retrieved from: http://data.worldbank.org/indicator/SP.POP.TOTL. (date of access: March 10, 2016).

${ }^{4}$ World Bank. (2015). Ease of doing business rank. Retrieved from: http://www.doingbusiness.org/rankings (date of access: March 10, 2016).
} 
dustry), which happened due to membership in MERCOSUR, explicitly shows the positive impact of regional integration on the manufacturing industry. Membership in MERCOSUR increased the FDI inflows into the automobile industry of Argentina. This capital was used to build new factories and to enlarge the existing ones in order to develop local production [12, p. 31]. Therefore, the regional economic integration made a significant contribution into the development of the manufacturing industry of developing and developed countries. Besides this, the EAEU might help to attract new FDI inflows into Belarus as this country is kind of a bridge between the EAEU and the western countries. Establishment of subsidiaries of transnational corporations within the territory of Belarus might help to avoid problems with exporting to Russia and the other EAEU Member States.

Nowadays the majority of the transnational corporations operating in the EAEU Member States are those which originate from developed countries such as the USA and the Member States of the EU. For example, British Petroleum (Great Britain), Royal Dutch (Netherlands/Great Britain), ConocoPhilips (the USA), Chevron Texaco (the USA), Exxon Mobil (the USA), Eni group (Italy), Total (France), etc. However, lately, the companies originating from the EAEU Member States tend to become stronger. Two countries of the EAEU, namely Russia and Kazakhstan, already have their large-scale business entities which deal with the extraction of natural resources, mainly oil and gas. For example, Alrosa, Gazprom, Lukoil, Mechel, Norilsk Nickel, RusAl, Severstal (Russia), "KazMunaiGaz", "Kazakhoil”, "Kazatomprom" (Kazakhstan), etc.

Moreover, Russia has been becoming a significant investor. It forms a part of the group of countries named BRICS (Russia, Brazil, India, China and South Africa), which is one of the leading FDI providers in the world ${ }^{1}$. In 2013, Russia almost doubled FDI outflows from $\$ 48822$ million to $\$ 94907$ million $^{2}$. Therefore there are significant preconditions for the further strengthening of Russian large business and its transnationalization

Thus, there are important prerequisites for further strengthening of Russian large-scale business and its transnationalization.

\footnotetext{
${ }^{1}$ UNCTAD (2015). World Investment Report: Reforming in ternational investment governance. New York and Geneva. Retrieved from: http://unctad.org/en/PublicationsLibrary/ wir2015_en.pdf (date of acceess: March 22, 2016).

${ }^{2}$ UNCTAD. (2014a). World investment report 2014 Investing in the SDGs: an action plan. New York and Geneva. Retrieved from: http://unctad.org/en/PublicationsLibrary/wir2014 en.pdf. 208-210 (date of access: December 17, 2015).
}

Examples of the strengthening of the largescale business from Kazakhstan can be found in certain transactions. For example, in 2012, the transaction for the $\$ 3$ billion on Karachaganak Petroleum gave a national company of Kazakhstan (KazMunaiGaz) a 10 percent stake in the joint venture of Karachaganak, along with co-owners Chevron Corp., Eni SpA and OAO “LUKOIL” 3 . Even though at the dawn of independence, Kazakhstan's economy has been completely dependent on foreign transnational corporations, now there are serious prerequisites for the strengthening of largescale national companies and their shift to the same level with foreign transnational corporations in the region.

Therefore, the creation of new transnational corporations by the accumulation of the resources of several EAEU Member States is the prospect of the near future. The large-scale business of the EAEU Member States in the sphere of energy resources is becoming a serious competitor for the foreign transnational corporations which came to the region in the 1990s and is getting ready to shift on the international level. The corporate integration can accelerate this process. Back in 2013, Belarus proposed the creation of transnational corporations within the CIS in order to profit from the potential of integration and to create the joint ventures, cooperative corporations, and financial-industrial groups ${ }^{4}$.

Development of the EAEC and its conjugation with the megaproject "Great Silk Road" (20 countries claimed their participation) can greatly contribute to the creation of new transnational corporations, because it gives to any large-scale business entity with a substantial package of assets and large amount of turns, established on the territory of one of the Member States, the necessary instruments to expand within the entire market of the EAEU.

\section{Conclusion}

The Eurasian Economic Union, which is a result of two-decades-long regional integration, is the international organization with a new format that has never existed within the Post-Soviet territory before. Due to the historical background,

\footnotetext{
${ }^{3}$ UNCTAD. (2014a). World investment report 2014 Investing in the SDGs: an action plan. New York and Geneva. Retrieved from: http://unctad.org/en/PublicationsLibrary/wir2014_ en.pdf. 208-210 (date of access: December 17, 2015).

${ }^{4}$ RBC (RosBusinessConsulting) information system. (2013). Belarus offers to create transnational corporations in frame of the CIS. Retrieved from: http://top.rbc.ru/economics/20/11/2013/889975.shtml. (dsate of access: November 10, 2014).
} 
the transnational corporations and their companies are an essential part of the economies of its Member States. It is evident that the EAEU would influence the future development of these business processes.

Firstly, the EAEU will most probably increase in general the amount of FDI inflows in the economies of its Member States because the regional integration usually is the factor which ensures economic stability. This fact is proved by the experience of other organizations of regional integration (European Union, MERCOSUR).

Secondly, the EAEU might stimulate FDI inflows in the manufacturing industry and service sector of the economies of Russia, Kazakhstan, Kyrgyzstan, Belarus, and Armenia because the integration enlarges the common market.
Thirdly, the establishment of the common markets within the EAEU might strengthen the resource-oriented large-scale companies originating from the Member States, mainly Russia and Kazakhstan and eventually form a groundwork for the creation of new transnational corporations in the frame of the EAEU.

However, the implementation of the above-mentioned prospects depends on the legislative initiatives which will be taken by the EAEU Member States in order to ensure the continued effective functioning of the Union. The harmonization of legislation and development of the EAEU law compose a necessary basis for effective economic integration. In this part, it seems reasonable to be guided by the experience of the existing regional associations.

\section{References}

1. Hood, N., \& Young, S. (2000). Globalizatsiya deyatelnosti mnogonatsionalnykh predpriyatiy i ekonomicheskoye razvitie. $1 \mathrm{izd}$. [The g lobalization of Multinational Enterprise Activity and Economic Development. 1st ed.]. UK: Palgrave Macmillan Publ., 418.

2. Machlinski, P. (2007). Mnogonatsionalnyye predpriyatiya i pravo [Multinational enterprises and the law]. Oxford: Oxford UP, 740.

3. Polyakov, V. \& Shchenina, R. (2008). Mirovaya ekonomika i mezhdunarodnyy biznes. 5 izd [World economy and world business. 5th ed.]. Moscow, 681.

4. McKern, R. B. and United Nations. (1993). Transnatsionalnyye korporatsii i ekspluatatsiya prirodnykh resursov [Transnational corporations and the exploitation of natural resources]. In: Bruce McKern (Ed.). London; New York: Routledge, 397.

5. Borensztein, E., De Gregorio, J. \& Lee, J. W. (1998, June 1). Kak pryamyye inostrannyye investitsii vliyayut na ekonomicheskiy rost? [How does foreign direct investment affect economic growth?]. Zhurnal mezhdunarodnoy ekonomiki [Journal of international economics], 45, 115-135.

6. Spitsyn, A. T. (2014). Integratsionnyy proekt planetarnogo masshtaba: Evraziyskiy ekonomicheskiy soyuz [Integration project of global scale: Eurasian economic union]. Moscow: Prospekt Publ., 60.

7. Zimin, V. A. (2010). Mirovaya ekonomika: Uchebno-metodicheskoye posobie [World economy: educational and methodological book. $2 d$ add. ed.]. Samara: AsGard Publ., 220.

8. Baldvin, R. \& Segetstsa, E. (1998). Regionalnaya integratsiya i rost i razvivayushchikhsya stranakh [Regional integration and growth in developing nations]. Zhurnal ekonomicheskoy integratsii [Journal of economic integration], 367-399.

9. Leshchenko, M. \& Demin, V. (2004). Innovatsionnaya i investitsionnaya strategiya stran SNG [Innovation and investing strategy of the CIS countries]. Moscow: RITTS MGIU Publ., 320.

10. Akunov, A. A. (1998). Postsovetskiy Kyrgyzstan glazami zarubezhnykh politologo [Post-Soviet Kyrgyzstan through eyes of foreign political scientists]. Obrazovatelnyy tsentr "Strategicheskie issledovaniya gosudarstvennoy sluzhby i politicheskiy ucheniy" [Educational center "Strategic research of state work and political sciences"], 149.

11. Ashimbaev, S. (2004). Aktualnyye voprosy sotsialno-ekonomicheskogo razvitiya Respubliki Kazakhstan na sovremennom etape: Nauchnoe izdanie [Actual problems of the social and economic development of the Republic of Kazakhstan in modern at present stage]. Almaty: Kazakhstan Presidential Institute of Strategic Research of the Republic of Kazakhstan Publ., 143.

12. Özden, Ç., \& Parodi, F. J. (2004). Tamozhennyye Soyuzy i zarubezhnyye investitsii: teoriya i dokazatelstva na primere avtomobilnoy promyshlennosti MERKOSUR [Customs Unions and Foreign Investment: theory and evidence from Mercosur's auto Industry]. Tsentarlnyy bank Chili, rabochie doklady [Central Bank of Chile, working papers], $282,31$.

13. Sidorovich, A. V. (2013). Evraziyskaya ideya i evraziyskie initsiativy N. A. Nazarbaeva na novom etape globalizatsii [Eurasian idea and Eurasian initiatives of N. A. Nazarbayev on the new level of globalization]. Miras, 4, 52-58.

14. Osipov, Yu. M. et al. (Eds). Evraziyskaya integratsiya: geostrategicheskiy aspect [Eurasian integration: geostrategic aspect]. Moscow: Vuzovskaya kniga Publ., 563.

15. Spitsyn, A. T. (2015). Globalnyye transformatsii i innovatsionnaya modernizatsiya ekonomiki $v$ XXI veke [Global transformation and innovative modernization of economy in 21st century]. Moscow: Ekonomika Publ., 351.

16. Spitsyn, A. T. (2016). Novaya industrializatsiya ekonomiki i perspektiv evraziyskoy integratsii, realizatsii transkontinentalnykh proektov XXI veke [New industrialization of the economy and prospects of the Eurasian integration, realization of transcontinental projects in 21st century]. Moscow: Prospekt Publ., 79. 
17. Transnatsionalnyye korporatsii $i$ transnatsionalnoye upravlenie: Tsena perekhoda [Transnational corporations and transnational governance: The cost of crossing]. Palgrave Macmillan Publ., 399.

18. Hamdani, K. A. \& Ruffing, L. T. (2015). Tsentr Organizatsii Obedinennykh Natsiy po transnatsionalnym korporatsiyam: korporativnoye povedenie i obshchestvennyye interesy [United Nations Centre on transnational corporations: Corporate conduct and the public interest]. London: Routledge, 295.

\section{Authors}

Anatoliy Tikhonovitch Spitsyn - Doctor of Economics, Professor, Russian Academy of National Economy and Public Administration (82, Vernadskogo Ave., Moscow, 119571, Russian Federation; e-mail: sspitsyn.anatolii@mail.ru).

Galiya Aidarovna Kulubekova - PhD, Postdoctoral Student, L.N. Gumiliov Eurasian National University (8, Abay Ave., Astana, 010000, Kazakhstan; e-mail: kulubekova.galiya@gmail.com). 